\title{
Effect of noise pollution on testicular tissue and hormonal assessment in rat
}

\author{
P. Farzadinia ${ }^{1}$, M. Bigdeli ${ }^{2}$, S. Akbarzadeh ${ }^{3}$, M. Mohammadi ${ }^{4}$, A. Daneshi $^{5}$ and A. Bargahi ${ }^{5}$ \\ 1 Department of Biology and Anatomical sciences, School of Medicine, Bushehr University of Medical Sciences, Bushehr, Iran; \\ 2 Department of Biology, Islamic Azad University, Jahrom Branch, Jahrom, Iran; \\ 3 Department of Biochemistry, School of Medicine, Bushehr University of Medical Sciences, Bushehr, Iran; \\ 4 Young researchers and elite club, Bushehr Branch, Islamic Azad University, Bushehr, Iran; \\ 5 The Persian Gulf Marine Biotechnology Research Center, Bushehr University of Medical Sciences, Bushehr, Iran;
}

\author{
Keywords \\ ACTH_cortisol_noise-testicular-testos- \\ terone \\ Correspondence \\ Dr Afshar Bargahi, The Persian Gulf Marine \\ Biotechnology Research Center, Bushehr \\ University of Medical Sciences, Boostan 19 \\ Alleys, Imam-Khomeini St., P. O. Box 75147- \\ 63448, Bushehr, Iran. \\ Tel.: +987733450692; \\ Fax: +987733450692; \\ E-mail: abargahi@yahoo.com
}

Accepted: November 2, 2015

doi: 10.1111/and.12524

\begin{abstract}
Summary
Many studies have focused on the effect of noise stress on the health. So far, few studies have been conducted on the effect of noise on reproductive system. The aim of study was to investigate the effect of noise pollution on morphometric parameters of testicular tissue and hormonal assessment (ACTH, cortisol and testosterone). In this study, 40 male rats were exposed to control, 95, 105 and $115 \mathrm{~dB}$ noise intensity for sixty days. At the end of study, blood sampling was performed and ACTH, cortisol and testosterone concentrations were assessed. The results showed that noise stress decreased testosterone levels in the $115 \mathrm{~dB}$-treated group, while it increased the ACTH and cortisol levels. Histological sections of testis showed that the mean diameter of the seminiferous tubules and thickness of the germinal epithelium reduced compared to the control group. Also the ratio of the interstitial tissue area to the total testicular tissue area was increased significantly. Our study shows that noise stress may have negative influences on male fertility.
\end{abstract}

\section{Introduction}

Environmental pollution is one of the human social problems leading to stress that impact on various aspect of the life in plants and animals (Sunjog et al., 2012). These factors include electromagnetic radiation, radio wave (Köbbert et al., 2008; Sánchez et al., 2009; Kuo \& Lu, 2012), ionising and nonionising radiation (Wang et al., 2012), heat stress, noise and vibration that come from many resources at work or home (Murata et al., 1990; Yavuz et al., 2006). In the atmosphere, some of these pollutants are related to noise pollution. In recent years, many investigations have focused on the effects of physical factors in the industrial environments on the human reproduction. Many studies have been conducted on the effects of noise disturbance on the auditory, circulatory and digestive system. Many studies have shown that stress increases the glucocorticoids (GCs) led to decreasing in testosterone levels. The negative impact of this factor on the hypothalamicpituitary-gonadal axis (HPG axis) may arise from the most significant negative effect of noise stress on the reproductive system (Monder et al., 1994). Noise stress is one of the most dangerous natural contaminant during our life, which produces harmful physiological, psychological and morphological outcomes to the reproductive system. It seems that the long-term exposure of noise stress has negative influences on the fertility of male based on enhancing the apoptotic process induced by pathogenesis stress and suppressing the kinetics of spermatogenesis (Jalali et al., 2013). Then, it is clear that noise as main environmental stress increases the release of hypothalamic hormones such as corticotropin-releasing hormone (CRH) and adrenocorticotropic hormone (ACTH). These hormones increase the activity of the hypothalamic-pituitary-adrenal axis (HTPA axis) and the release of corticosteroids such as cortisol from the adrenal cortex (Maschke et al., 1995; Ogale, 1999). The noise stress has negative effects on the biological processes and embryonic development. Also this factor causes disorders in social behaviour and regulation of the HTPA axis. Stress is associated not only with impaired maternal neuroendocrine system during pregnancy, but also with reduced birthweight and decreased implantation in the uterus (Maschke, 1982). One of the noisiest environments is industrial working places such as metal turnery and blacksmithing (Henderson et al., 2006). Some men work for a long time in these places, and then, they exposed to 
high intensity of noise disturbance. Therefore, the aim of study was to investigate the effects of noise pollution on morphometric parameters of testicular tissue and hormonal assessment (ACTH, cortisol and testosterone).

\section{Materials and methods}

According to this study, 40 adult male Wistar rats weighing $200 \pm 20 \mathrm{~g}$ at 70 to 80 days of age were divided into four equal groups like the following: the first group (I) was kept in a silent environment as the control group. Group II, III and IV were exposed to 95, 105 and $115 \mathrm{~dB}$ noise intensity, respectively, for 60 days (two hours per day). In the workshop metal turnery, the sound was recorded using a digital recorder (RX-DT 707, Panasonic, Taiwan). The output of the recorder was amplified (Pyramid Studio Pro Pa-600×, Pioneer Corporation, Tokyo, Japan) and delivered to speakers. Sound intensity was controlled and regulated by sonometer (TES-1358, TES Electrical Electronic Corp., Taiwan). Noise frequencies were between 8 and $10 \mathrm{kHz}$. All animal experiments were carried out in accordance with instructions of the ethic committee of animal research of the Bushehr University of Medical Sciences, Bushehr, Iran.

Animals were housed in $22-24{ }^{\circ} \mathrm{C}, 40-60 \%$ humidity and 12-h dark/light cycle conditions. Animals were freely accessed to water and rat food. Two rats were placed in each cage to diminish the loneliness stress. At the end of the study, the rats were anaesthetised using ketamine (50 mg/kg, IM), and then, the blood sampling was performed. Then, testis biopsies were performed after scarify- ing. Levels of ACTH, cortisol and testosterone hormones were assessed by the chemiluminescence method (Electro Chemiluminescence, Alexis device model Elecsys E411, Roche, Geislingen, Germany). For histological evaluation, the testis was removed from the scrotal sac and was cut into small pieces and specimen was placed in 10\% formalin fixative solution immediately. After fixation for light microscopy, the specimens were dehydrated with ethanol, infiltrated and embedded in paraffin. Three-micron sections were prepared using a rotary microtome (RM2125, Leica, Leica Biosystems Nussloch GmbH, Heidelberger, Germany) and stained (H\&E). The micrographs were taken by light microscope equipped with a digital camera (Moticam pro 280; Motic Instruments Inc., Xiamen, China) and evaluated using of the Image Tool (version 6 UTHSCSA, San Antonio, Texas, USA) software. The morphological changes in tissues such as inflammation, regeneration of the seminiferous tubules were studied. Morphometric analysis of tubules and diameters or thicknesses of seminiferous was evaluated.

\section{Statistical analysis}

The experimental results were averaged, and statistical analysis was performed using the SigmaStat Software package (SPSS Science, Chicago, IL, USA). Data were analysed for normality followed by analysis of variance. Data obtained from hormone assessments and histological parameters were evaluated statistically by one-way ANOVA method followed by the Dunnett test. The results were shown as Mean $\pm \mathrm{SD}$ and $P<0.05$.
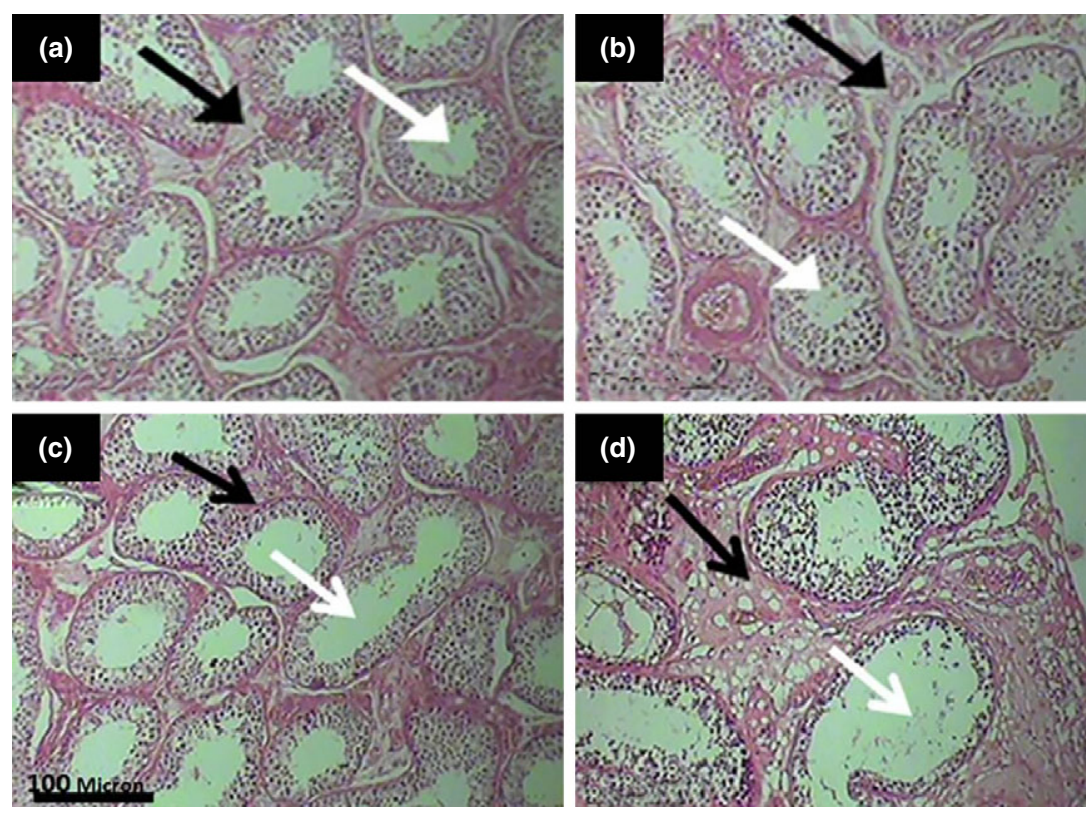

Fig. 1 Photomicrographs of rat testicular tissue. (a) Control group; (b) Group that exposed to $95 \mathrm{~dB}$; (c) Group that exposed to $105 \mathrm{~dB}$ and (d) Group that exposed to $115 \mathrm{~dB}$ of noise. Germinal epithelium of seminiferous tubules (white arrow), interstitial connective tissue (black arrows). (H\&E, $\times 100)$. 


\section{Results}

\section{Morphologic}

The morphological findings of testicular tissues in the different groups were shown in Fig. 1. In the control group, thickness of germinal epithelium of seminiferous tubules was normal. Also, connective tissue among tubules was completely regular and uniform and no histopathological changes such as inflammation and congestion were observed in the control group. While slightly seminiferous tubules become atrophy and increasing in interstitial tissue revealed in the groups that exposed to the noise with intensity of 95 and $105 \mathrm{~dB}$ respectively. Also the seminiferous tubule diameter and germinal epithelium thickness have been decreased, and connective tissues between tubules have increased severely as fibrotic changes and vacuolisation have observed in histological section of $115 \mathrm{~dB}$ group comparing to the control group.

\section{Morphometric}

The diameter of seminiferous tubule and germinal epithelium thickness is reduced significantly in the animals exposed to $115 \mathrm{~dB}$ noise intensity, while there was no significant difference between treated groups with 95 and $105 \mathrm{~dB}$ intensity comparing to the control group. The ratio of interstitial tissue area to the total testicular tissue area (ITA/TTA) in the $115 \mathrm{~dB}$-treated group increased significantly comparing to the control group, while this ratio in the $95 \mathrm{~dB}$ - and $105 \mathrm{~dB}$-treated groups was not significant (Table 1).

\section{Hormonal assessments}

Blood concentrations of ACTH and cortisol have increased significantly, although testosterone decreased in the group exposed to $115 \mathrm{~dB}$ noise intensity. But, the concentration of these hormones showed there are no significant difference between the treated groups with 95 and $105 \mathrm{~dB}$ comparing to the control group (Table 2).

\section{Discussion}

Noise stress has an effect on the activity of neuropeptides in hypothalamic and extrahypothalamic sites and significantly it causes an increase in the secretion of hypothalamic hormones such as CRH and ACTH (Michaud et al., 2003). In addition to extra hypothalamic effects, these hormones increase the activity of the HTPA axis and stimulate release of corticosterone such as cortisol from the adrenal cortex (Spreng, 2000). Chronic stress caused by noise may change constant hormone levels and their metabolisms that can weaken function of some systems such as the reproductive system (Negro-Vilar, 1993).

Recent studies have shown strong audio signals cause neuroendocrine changes in the humans and animals. Their effects are similar to the stressful factors such as elevated levels of ACTH, glucocorticoids and catecholamines (Windle et al., 1997). In the present study, the blood ACTH and cortisol concentrations were increased significantly in treated group with $115 \mathrm{~dB}$ noises compared with the control, while testosterone level decreased (Table 2). Environmental factors, including chemical, physical or emotional, have detrimental effects on testicular function (Singh \& Sharma, 2011). Stress is a potential stimulus that causes disorder in the HPG axis (Norman \& Smith, 1992) and decreases plasma $\mathrm{LH}$ and testosterone levels (Knol, 1991). In consistent with these findings, as shown in the Table 2, the level of testosterone decreased due to the effects of noise stress on the hypothalamic-pituitary-testicular axis. Traffic noise increases the level of testicular cholesterol significantly (Pramanik \& Biswas, 2012). Their study has shown that exposure to noise reduces testosterone biosynthesis and cholesterol accumulation (due to impaired cholesterol to testosterone conversion) in testis. Noise exposure leads to inhibition of the enzyme activity, which could be due to inhibition of the pituitary gonadotropin-releasing hormone. Recent studies showed that exposure to traffic noise (acute and chronic) with intensity of 80 to $90 \mathrm{~dB}$ has detrimental effects on testicular weight, sperm counts and morphology in rats (Babisch, 2006). These effects could be due to impaired regulation of spermatogenesis. However, in our study, qualitative and quantitative changes of testicular parameters were only observed

Table 1 Effect of noise intensity on morphometric parameters of rat testicular tissue

\begin{tabular}{|c|c|c|c|c|}
\hline \multirow[b]{2}{*}{ Parameter } & \multicolumn{4}{|l|}{ Group (intensity) } \\
\hline & Control & $\mathrm{I}(95 \mathrm{~dB})$ & II (105 dB) & III (115 dB) \\
\hline Germinal epithelium thickness ( $\mu \mathrm{m})$ & $101.11 \pm 2.11$ & $98.17 \pm 1.8$ & $97.12 \pm 2.09$ & $61.45 \pm 2.15^{*}$ \\
\hline$\%$ ITA/TTA & $16.44 \pm 1.55$ & $15.13 \pm 1.13$ & $22.67 \pm 1.29$ & $58.67 \pm 1.11 *$ \\
\hline
\end{tabular}

* Significant difference from control group $(P \leq 0.05)$; ITA/TTA, ratio of interstitial tissue area to the total testicular tissue area. 
Table 2 Effect of noise intensity on blood ACTH, cortisol and testosterone concentration

\begin{tabular}{|c|c|c|c|c|}
\hline \multirow[b]{2}{*}{ Parameter } & \multicolumn{4}{|l|}{ Group (intensity) } \\
\hline & Control & I (95 dB) & II (105 dB) & III (115 dB) \\
\hline ACTH $\left(p g \mathrm{ml}^{-1}\right)$ & $198.94 \pm 73.71$ & $175.2 \pm 78.24$ & $176.45 \pm 57.54$ & $279.18 \pm 83.08 *$ \\
\hline Cortisol (ng ml ${ }^{-1}$ ) & $26.55 \pm 12.99$ & $27.05 \pm 15.52$ & $22.96 \pm 11.64$ & $60.22 \pm 37.22 *$ \\
\hline Testosterone $\left(\mathrm{ng} \mathrm{ml}^{-1}\right)$ & $3.001 \pm 2.34$ & $2.04 \pm 1.38$ & $2.33 \pm 1.46$ & $0.57 \pm 0.42^{*}$ \\
\hline
\end{tabular}

*Significant difference from control group $(P \leq 0.05)$.

in $115 \mathrm{~dB}$-treated group. The seminiferous tubules have dilated abnormally, the germinal epithelium has atrophied, and connective tissues between tubules have severely increased (Fig. 1 and Table 1). Then, connective tissues become severely increased as fibrotic changes and vacuolisation.

Degeneration of germinal epithelium cells occurs constantly, especially during the first spermatogenesis cycle. It seems that degeneration of germ cells in testis mediated through the apoptotic process and has essential role in limiting the number of germ cells which mediated by a Sertoli cell. The changes in high-regulated environment of testis, such as decline of androgen levels (Tapanainen et al., 1993), enhancement of temperature in testis (Yin et al., 1997) and overactivation of a sertoli cells (Cai et al., 1997), can activate apoptosis in male gametes. On the basis of above the study, reducing the amount of testosterone in the treated group with $115 \mathrm{~dB}$ noise intensity can reduce sperm production and increase apoptosis in our study. Therefore, these changes lead to reduction in the thickness of germinal epithelium and diameter of the seminiferous tubules (Fig. 1). There are five cellular layers of spermatogenesis in wall of seminiferous tubule, such as spermatogonia, primary spermatocyte, secondary spermatocyte, spermatid and spermatozoa, so the rate of spermatogenesis activity reduces, the number of spermatozoa decreases and so the total diameter of seminiferous tubules decreases (Fig. 1 and Table 1). Some maturation of germ cells can be stopped in chronic noise exposure due to the decrease in the testosterone level and probably proliferation of Leydig cells. This is a compensatory mechanism for the increase of testicular steroidogenesis to compensate low levels of testosterone (Mylchreest et al., 2002). In the present study, the ratio of interstitial tissue area to the total testicular tissue area (ITA/TTA) in the treated group with $115 \mathrm{~dB}$ was increased compared with the control group (Table 1). These changes may be the cause for the decrease in the concentration of testosterone hormone.

\section{Conclusions}

Noise exposure of $115 \mathrm{~dB}$ to the testicular tissue decreases the testosterone level while increases ACTH and cortisol and also induces atrophy in germinal epithelium cells and abnormal dilation of seminiferous tubules, decreasing the thickness of the germinal epithelium and mean diameter of the seminiferous tubules. Noise exposure increases the ratio of total interstitial tissue area (ITA) to the total testicular tissue area (TTA) as well.

\section{References}

Babisch W (2006) Transportation noise and cardiovascular risk: updated review and synthesis of epidemiological studies indicate that the evidence has increased. Noise Health 8:129.

Cai L, Hales BF, Robaire B (1997) Induction of apoptosis in the germ cells of adult male rats after exposure to cyclophosphamide. Biol Reprod 56:1490-1497.

Henderson D, Bielefeld EC, Harris KC, Hu BH (2006) The role of oxidative stress in noise-induced hearing loss. Ear Hear 27:1-19.

Jalali M, Hemadi M, Saki G, Sarkaki A (2013) Study of spermatogenesis fetal testis exposed noise stress during and after natal period in rat. Pak J Biol Sci 16: $1010-1015$.

Knol BW (1991) Stress and the endocrine hypothalamuspituitary-testis system: a review. Vet Q 13:104-114.

Köbbert C, Berndt A, Bierbaum T, Sontag W, Breithardt G, Weissen-Plenz G, Sindermann JR (2008) Low-energy electromagnetic fields promote proliferation of vascular smooth muscle cells. Electromagn Biol Med 27:41-53.

Kuo YC, Lu CH (2012) Expression of P-glycoprotein atrophied and multi drug resistance-associated protein on human brain-microvascular endothelial cells with electromagnetic stimulation. Colloids Surf Biointerfaces 91:57-62.

Maschke JP (1982) Effects of noise on growth and reproduction of crangon in rearing tanks. Mar Biol 71:177185.

Maschke C, Ising H, Arndt D (1995) Night licher and health: results from laboratory and field studies. Bundesgesundheitsblatt 4:130-137.

Michaud DS, McLean J, Keith SE, Ferrarotto C, Hayley S, Khan SA, Anisman H, Merali Z (2003) Differential impact of audiogenic stressors on Lewis and Fischer rats: behavioral, neurochemical, and endocrine variations. Neuropsychopharmacology 28:1068-1081. 
Monder C, Miroff Y, Marandici A, Hardy MP (1994)

$11 \beta$-hydroxy steroid dehydrogenase alleviates glucocorticoid-mediated inhibition of steroidogenesis in rat Leydig cells. Endocrinology 134:1199-1204.

Murata M, Kawade F, Kondo M, Takigawa H, Skamoto H (1990) Effects of audiogenic hazard on fetal skeletal development in mice. J Sound Vib 139:307-311.

Mylchreest E, Sar M, Wallace DG, Foster PM (2002) Fetal testosterone insufficiency and abnormal proliferation of leydig cells and gonocytes in rats exposed to di (n-butyl) phthalate. Reprod Toxicol 16:19-28.

Negro-Vilar A (1993) Stress and other environmental factors affecting fertility in men and women: overview. Environ Health Perspect 101(Suppl 2):59-64.

Norman RL, Smith CJ (1992) Restraint inhibits luteinising hormone and testosterone secretion in intact male rhesus macaques: effects of concurrent naloxone administration. Neuroendocrinology 55:405-415.

Ogale SB (1999) Noise overload. Health Nutr 85-89.

Pramanik P, Biswas S (2012) Traffic noise: a silent killer of male gamete of albino rats. Al Ameen J Med Sci 5:8289.

Sánchez R, Kim MY, Calonje M, Moon YH, Sung ZR (2009) Temporal and spatial requirement of EMF1 activity for arabidopsis vegetative and reproductive development. Mol Plant 2:643-653.
Singh AK, Sharma RC (2011) Effects of stress on epididymis in albino rat. Int J Med Clin Res 2:20-21.

Spreng M (2000) Central nervous system activation by noise. Noise Health 7:29-37.

Sunjog K, Gačić Z, Kolarević S, Višnjić-Jeftić Ž, Jarić I, Knežević-Vukčević J, Vuković-Gačić B, Lenhardt M (2012) Heavy metal accumulation and the genotoxicity in barbel (Barbusbarbus) as indicators of the Danube river pollution. Sci World J 57:487-492.

Tapanainen JS, Tilly JL, Vihko KK, Hsueh AJ (1993)

Hormonal control of apoptotic cell death in the testis: gonadotropins and androgens as testicular cell survival factors. Mol Endocrinol 7:643-650.

Wang S, Lee J, Ro JY, Chung MK (2012) Warmth suppresses and desensitizes damage-sensing ion channel. Mol Pain 8:22.

Windle RJ, Wood S, Shanks N, Perks P, Conde GL, da Costa AP, Ingram CD, Lightman SL (1997) Endocrine and behavioral responses to noise stress: comparison of virgin and lactating female rats during non-disrupted maternal activity. J Neuroendocrinol 9:407-414.

Yavuz Y, Skogås JG, Güllüoğlu MG, Langø T, Mårvik R (2006) Are cold light sources really cold? Surg Laparosc Endosc Percutan Tech 16:370-376.

Yin Y, Hawkins KL, DeWolf WC, Morgentaler A (1997) Heat stress causes testicular germ cell apoptosis in adult mice. J Androl 18:159-165. 